\title{
The nexus Between the Growth of Microfinance Institutions and the Macroeconomic Context in Vietnam
}

\author{
Hoai Thi Thu Tran*
}

\begin{abstract}
The aim of this paper is to provide an overview of the development of the microfinance sector in Vietnam and to examine the link between microfinance institution development and domestic economic factors. Particularly after reviewing previous papers conducted all over the world, this paper examines the Vietnamese market by using five years (2010-2015) of data from Vietnamese microfinance institutions by using a descriptive statistical method. It was found that the growth of gross domestic product (GDP) and gross loans portfolio more or less have a relation. Likewise, foreign direct investment (FDI) inflow growth seems to have a link with asset development. This result also opens up several avenues for future research. Further studies could be performed to examine data with a quantitative method to test the results.
\end{abstract}

Keywords: microfinance, macroeconomic, growth

\section{Introduction}

The Microfinance institution (MFI) is known as an institution which supports the poor to access financial services. In the late 1980s, while Vietnam was undergoing economic improvement, international organizations, non-governmental organizations and official aid programs introduced microfinance activities in Vietnam. From this time to now, microfinance in Vietnam has experienced great development, having an important contribution to the reduction of poverty.

In 2015 in Vietnam about 69\% of its citizens could not access official financial services (United Nation, 2015). Most of them did not have the chance to use banking services but they had demand in deposits or loans. Clearly, the demand for microfinance services (deposits, loans, insurance, financial management, risk management) is significant.

To sum up, the scale of microfinance activities in Vietnam has increasingly expanded since 2005. So far, microfinance service providers have confirmed its important role in socio-economic development in general and poverty reduction in particular. Thanks to MFIs, Vietnam's poverty rate fell from almost $60 \%$ in the early 1990 s to $20.7 \%$ in 2010 (World Bank, 2012).

\footnotetext{
* Bachelor student at the National Economics University, Vietnam, Exchange student at the University of Szczecin, e-mail: hoaitran.160994@gmail.com/ttran@wneiz.pl.
} 
Therefore, the development of the microfinance sector in Vietnam is a key point, which leads to potential growth in the future. This, thus, means that it is imperative to study the determinants of microfinance growth, which helps policy makers forecast and give rational policy. In this paper, domestic economic effect will be studied.

This paper examines how the activity of MFIs varies with changes in the domestic economy of an institution. First, the author reviews the literature about macroeconomic condition effects on MFI activity and ways to measure microfinance outreach. After that, data is collected to study the growth of MFIs in the context of the changes in the macroeconomic, which provide evidence to realize whether the domestic economy has had an impact on the MFIs operation result or not. Finally, a conclusion is given by suggesting further avenues of research.

\section{Literature review}

There is rapidly growing literature evaluating MFI success and failure or MFI growth, which analyses the effect of macroeconomic factors on the activity of MFIs. In which, there have been mainly two methods used, namely a descriptive statistic method and a quantitative method.

The first one is a qualitative analysis. Most of the papers using this method concluded that macroeconomic condition has no effect or has a weak impact on microfinance activity.

McGuire and Conroy (1998) used the data of nine countries in Asia to observe the effects of the financial crisis in 1997 on the performance of MFIs in these countries. They studied the percentage changes in loans, savings, total assets and stocks of MFIs over a continual six-month period from 1996 to 1998. Interestingly, they found that institutions that serviced poor clients operated healthily during the financial crisis, which means that the crisis did not affect strongly on the financial situation of MFIs. The researchers gave a supposition that the crisis may affect MFIs and programs with a lag. Moreover, the research also concluded other important conclusions such as during the crisis the poorer countries were less affected than others. In addition, the institutions with poorer borrowers were better off and MFIs maintained lower interest rates while commercial banks increased their interest rates gradually.

Similarly, Marconi and Moseley (2005) collected data yearly from MFIs and commercial banks in Bolivia from 1998 to 2004, observing a total portfolio and each category in the portfolio in the context of a downturn in the economy. They put forward the claim that MFIs faced less difficulty than commercial banks in the recession. MFIs mainly serve poor women, lend in group and provide additional non-financial services such as training life skills, which had high repayment rates while commercial banks faced losses on bad-debt.

The research of Patten et al. (2001) studied the Bank Rakyat in Indonesia during the East Asian Crisis as a case study of microfinance success in the context of macroeconomic failure in the 1990s. This study provided confirmatory evidence that the repayment rate 
remained in the financial recession. Notably, the nominal interest rate went up by $13 \%$ while the annual inflation was $50 \%$, which is the reason why the real interest rate was lower in that period. This led to the fall in the revenue per dollar loaned, as a result of the crisis.

The above research all confirmed that the economic downturn had an insignificant relation with microfinance activity. On the other hand, Loncar et al. (2009) explored the microfinance industry in Eastern Europe and how its operation has been affected by the economic downturn of 2008-2009, which developed a claim that the economic recession makes the microfinance sector go down dramatically: the lower the growth in loans and deposits, the riskier the financial situation, meaning worse liquidity. They concluded that Eastern Europe is the most affected microfinance region from this recession in the world, which means that Eastern Europe is excessively vulnerable to contemporary economic trends.

Furthermore, Goenka and Henley (2010) based on historical evidence in the 20th century in Indonesia to claim that macroeconomics growth contributed remarkably to the success of microfinance in Indonesia.

The next method is a quantitative method. On the contrary with theoretical method, research carried out using the quantitative method showed different conclusions. Some of them concluded that macroeconomic condition has an impact on microfinance activities while some other authors saw no relation at all. Moreover, the impact level in each research also is not the same.

Gonzalez (2007) studied with a sample consisting of 639 MFIs in 88 countries from 1999 to 2005 , presenting the findings of an empirical analysis. Their estimation developed the claim that there was no relationship between changes in gross national income (GNI) per capita and asset quality. Moreover, researchers also saw no significant relationship between changes in GNI per capita (and its lag) and Risk over 90 days, Loan Loss Rate, and Write-off ratio.

Correspondingly, Muriu (2011) examined the MFIs profitability in 210 MFIs across 32 African countries between 1997 and 2008. Return on asset (ROA) and return on equity (ROE) were used to measure profitability, which depends on macroeconomics variables such as gross domestic product (GDP) per capita and inflation. The data yielded by this provided convincing evidence that these macroeconomic variables have no impact on MFIs profitability.

Likewise, Hermanto and Astuti (2013) analysed the macroeconomic impacts on the financial activity of MFIs in Java, Indonesia, using quarterly financial data from 2011 to 2012 of 858 MFIs. The financial result is measured by profitability and asset quality, while macroeconomic indicators are measured by GDP growth and inflation rate. Research findings lend support to the claim that the location has an impact on the financial result of MFIs in Java, the MFIs in East Java have the biggest profitability and the lowest NPL ratio in Java. More importantly, there is no significant impact of macroeconomic indicators on the MFIs' profitability, but there is a negative impact of inflation on the MFIs' NPL ratio.

Wooley (2008) conducted some research with 3,258 observations from 2000 to 2006, having a slight difference from the above papers by looking at both financial and outreach 
variables. The researcher looked at correlations between three financial variables (the growth of Operational Self-Sufficiency, the growth of profit margin, the growth of a portfolio at risk at more than 30 days) and two outreach variables (the growth in number of borrowers, the growth of average loan size) with GDP growth. The result can be summarized that none of these variables and GDP growth are significantly correlated. This result suggested that institutions can operate successfully in situations of low GDP growth, that they do not necessarily maintain high financial success at the expense of outreach and that perhaps there are some intrinsic characteristics of MFIs that make them so resilient.

In contrast with Wooley (2008) who concluded that there is no significant impact of macroeconomic indicators on the MFIs' profitability, Ahlin and Lin (2006) came up with an opposite conclusion. The purpose of the study conducted by Ahlin and Lin (2006) was to analyse the impact of macroeconomic variables on the activity of MFIs from 48 countries. Activity is measured based on profitability and efficiency. The dependent variables are operational self-sufficiency, write-off ratio, at-risk ratio, cost per borrower and the growth of MFIs while independent variables are GDP per capita and inflation. Summing up, the available evidence seems to suggest that the macroeconomic condition is an important determinant of MFI activity.

As an upgrade level of the paper by Ahlin and Lin (2006), Ahlin and Lin (2010) gathered the data of 373 MFIs from around the world and merged it with country-level economic and institutional data. They used more independent variables, constituting macroeconomic (such as GDP per capita, growth in GDP, domestic credit to the private sector, percentage of service in GDP, percentage of industry in GDP or inflation, ...) and institutional variables (such as the cost of starting a business, time of operation, ...) to assess the effect on the growth of the MFI. The growth of MFIs is measured by a subset of dependent variables, comprising MFIs borrower growth, loan-size growth, and portfolio growth. With these variables they used OLS regression and found that the share of GDP in service is positively associated with the MFIs borrower growth. Conversely, the share of GDP in industry predicts a slower MFI borrower growth and slower loan-size growth. Moreover, the relation between foreign direct investment (FDI) and loan-size growth is positive, which is explained in that FDI inflows may raise wage employment, creating demand complementarities for the micro-enterprises sector that spur MFIs intensive growth, but at the same time potentially limiting MFIs extensive growth. Besides, the researchers also showed that higher inflation also leads to slower loan-size growth.

Similarly, Vanroose (2008) applied a cross-country analysis on a dataset covering 115 countries. They used a regression model to assess the effect of variables including policy variables, geographic variables, and institutional variables on the development of the microfinance sector which measuring by the percentage of population served by MFIs in each country. There is growing support for the claim that microfinance reaches more clients in the richer countries of developing regions. In addition, countries that receive more international aid have a more developed microfinance market and the higher density of population, 
the more clients MFIs reach. From this paper it could be stated that domestic economies have considerable influence on the result of the MFIs outreach.

Imai et al. (2011) wrote a paper with data about 3,126 MFIs in 97 countries from 2005 to 2008 concerning regressed models with macro-institutional variables. In this study the researcher put forward the claim that macroeconomic and financial factors, such as GDP per capita, share of domestic credit to GDP, have positive impacts on MFIs financial result, such as profitability, operating expense and portfolio quality. Moreover, most institutional factors also express a positive impact in the financial results. Thus, it can be confirmed that macroeconomic factors are important, improving macro-institutional factors, and policies to raise country-level institutional qualities are required for making the activities of MFIs more sustainable, especially under a global recession.

In conclusion, among these papers, the results are not unanimous. Clearly, in each market, the impact of macroeconomic on microfinance should be different. This is the reason why this paper is concerned with examining the effect of macroeconomic on microfinance activity in Vietnam.

\section{The growth of the microfinance sector in the macroeconomic condition}

\subsection{The general development of the microfinance sector in Vietnam}

During 1993-2004, a number of microcredit programs of international NGOs, domestic organizations and individuals were expanding their scale and coverage in Vietnam. However, since 2005 up to now, most of the big programs of the above organizations have stopped or have been phased out of Vietnam. Experience and the funding of these programs have been transferred to local partners for continuation.

In an overview, the scale of microfinance activities in Vietnam has increasingly expanded since 2005. Looking exclusively at micro credit, the number of customers and total value of loans have maintained their growth over the years.

\section{Table 2}

The development of the microfinance system in Vietnam from 2005 to 2014

\begin{tabular}{llllll}
\hline \multirow{2}{*}{ Institution } & \multicolumn{5}{l}{ Number of borrowers (million) } \\
\cline { 2 - 6 } & 2005 & 2010 & 2012 & 2013 & 2014 \\
\hline Vietnam Bank for Social Policy & 3.8 & 7.8 & 5.76 & - & 6.9 \\
Vietnam Bank for Agriculture and Rural Development & 2.88 & 3.2 & 1.63 & - & 1.49 \\
People's Credit Fund & 0.85 & 0.95 & 1.07 & 1.12 & 1.23 \\
Formal and semi-formal MFIs & 0.28 & 0.6 & 0.48 & 0.5 & 0.8 \\
\hline Total & 7.81 & 12.5 & 9.19 & - & 10.42 \\
\hline
\end{tabular}

Source: ADB: "Sector Assessment: Microfinance", Documents prepared for the loan small program (SP2) Development microfinance sector Programme in Vietnam”, 2014. 
Despite a smaller scale in comparison with other service providers (Vietnam Bank for Social Policy, Vietnam Bank for Agriculture and Rural Development, People's Credit Funds system), MFI's growth in the customer base and loans portfolio is stable. In 2012, there was a decrease in the number of microfinance customers from 600,000 in 2010 to 480,000 in 2012, the reason for this is that many customers "graduated" and became "micro enterprises" and thus, they were able to access the services of official financial institutions. These customers may continue their client-ship with the MFIs who were "faithful companions over hardships" side by side with them over difficulties in the early stages. However, the regulated ceiling of 30 million Vietnam Dong (1,500 USD) for microfinance loans - much lower than their needs is also a reason. By 2013, the number of customers was increased, which is thanks to the expansion of some formal and semi-formal MFIs in resource mobilization and outreach to the niche market segment of the nearly poor in urban and rural areas.

Although the microfinance sector experienced a drop from 600,000 customers in 2010 to 480,000 customers in 2012 , the outstanding loan increase is $140 \%$. This means that the average loan-size went up significantly, which climbed from about 125 USD from 2010 to about 250-375 USD in the period of 2012-2014.

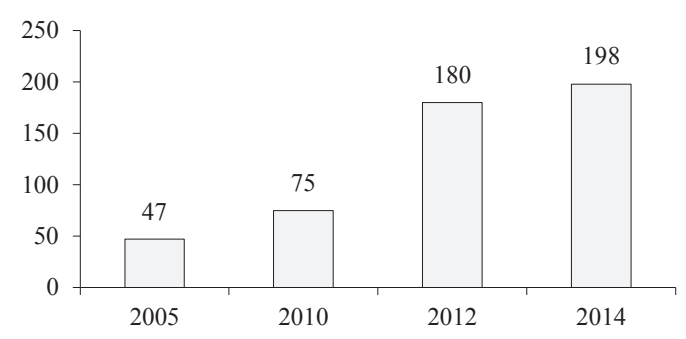

Figure 1. Outstanding loans of the Vietnam MFI sector from 2005 to 2014 (million USD)

Source: similar to Table 2 .

\subsection{The growth of the microfinance sector in the context of macroeconomic condition}

The next step is to assess the effect of macroeconomic factors to the development of the microfinance sector. GDP growth and FDI inflow will be used as domestic economic condition, which are considered to know the relation as well as the effect on the growth of asset, gross loan portfolio and deposit in the microfinance industry in Vietnam from 2010 to 2015.

First, the author observed the growth of the microfinance sector in the context of GDP growth.

Microfinance activity and GDP growth is the common topic of the previous paper as revived in the literature review. Most of them confirmed that GDP growth did not have any relation with loan growth, or deposit growth of the microfinance sector. Looking at above graph showing the change of GDP and the assets growth of MFIs in Vietnam, it seems 
that there is no relation between GDP growth and the MFIs assets growth. In the period of 5 years, the growth of GDP hit rock bottom exclusively one time in 2012, after that it climbed gradually to 2015. However, the development of assets witnessed a fluctuation between about 18 and $29 \%$. Clearly though, no links can be seen between them. Similarly, by looking at the second graph indicating the changes of GDP growth with two other aspects, there seems to be no relation in the growth of GDP and growth of deposits.

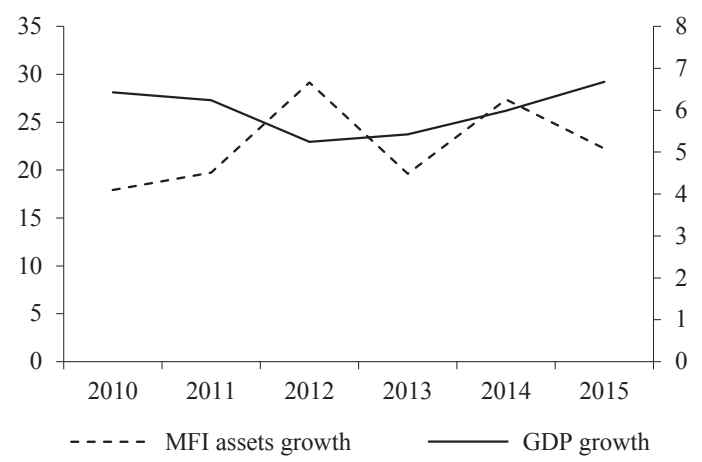

Figure 2. The growth of GDP and the growth of assets in microfinance institutions in Vietnam from 2010 to 2015

Source: self-calculation from World Bank data: http://data.worldbank.org and The Microfinance Information Exchange: https://www.themix.org/mixmarket (accessed 13.01.2017).

As a result, it can be concluded that within 5 years from 2010 to 2015, GDP growth may not have any relations with the MFIs assets and deposit development as well. This conclusion is the same with the conclusions of other researchers such as Wooley (2008), Bambang (2013) and Ahlin and Lin (2006).

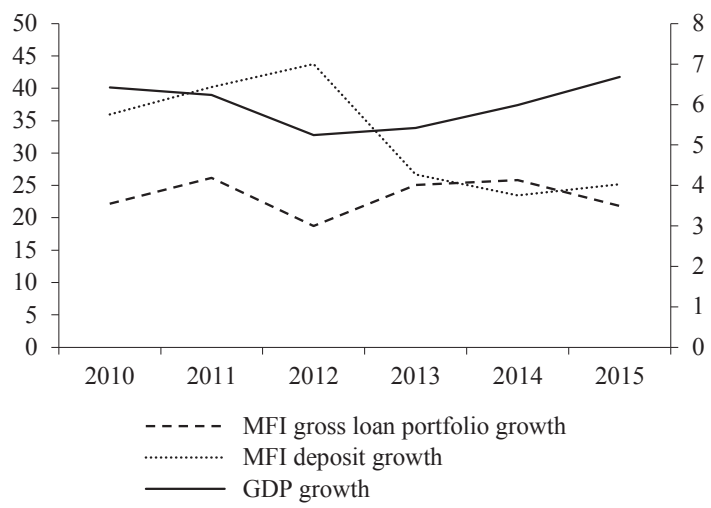

Figure 3. The growth of GDP, the growth of gross loan portfolio and deposit in microfinance institutions in Vietnam from 2010 to 2015

Source: similar to Figure 2. 
On the contrary, it seems that there is a relation between GDP growth and gross loan portfolio development (Figure 3). Considering the general trend, both of them reached a low after dropping gradually from 2010, then go in an upward trend towards the end of the period. This result probably has more or less the same similarities with the conclusion in the paper of Ahlin and Lin (2010) who found that the share of GDP in service is positively associated with the MFIs borrower growth.

Secondly, FDI inflow development is also a domestic factor which the author would consider. The idea about the research of the development of FDI inflow was initiated after reading the paper of Ahlin and Lin (2010) which also collected FDI data to assess the impact on MFIs activity.

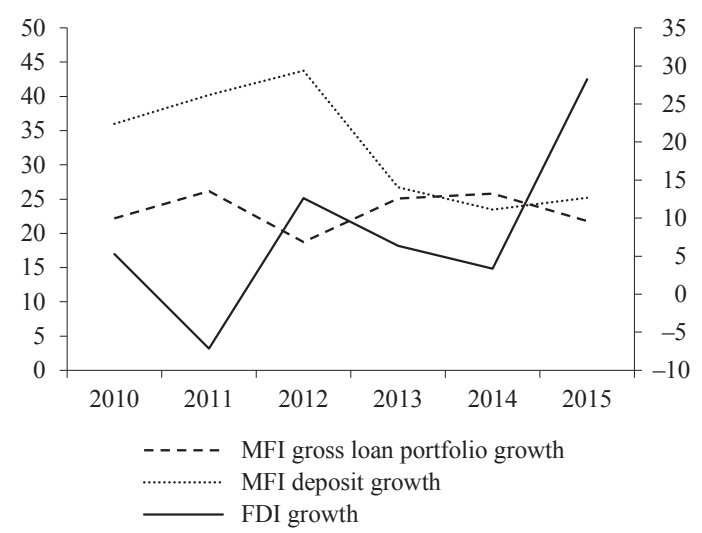

Figure 4. The growth of FDI, the growth of gross loan portfolio and deposit in microfinance institutions in Vietnam from 2010 to 2015

Source: similar to Figure 2.

From Figure 4, the author does not see any relation in the growth of FDI and the development of gross loan portfolio and the development of deposit growth.

However, it is interesting that in Figure 5 the graph shows similar changes in the growth of FDI inflow and the growth of MFIs asset, with the same shape being expressed in these two lines.

Both of the lines went up from 2011 to peak in 2012, with the asset growth hitting a high of $29.56 \%$ and FDI inflow reaching a peak of $12.62 \%$. After that asset growth fell to $19.19 \%$ in 2013 while FDI growth declined to $3.37 \%$ in 2014. Similarly, they grew again after one year. Maybe, there is a time lag. There is a possibility that FDI inflow has a relationship with MFIs asset. It is too early to conclude but at least from 2010 to 2015, it can be said to be true. 


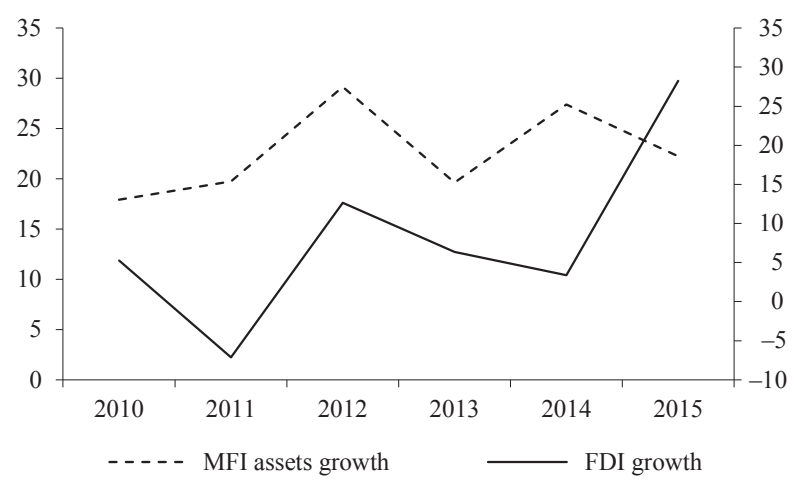

Figure 5. The growth of GDP and the growth of assets in microfinance institutions in Vietnam from 2010 to 2015

Source: similar to Figure 2.

As Ahlin and Lin concluded (2010), it can be explained for this positive relation that FDI inflows may raise wage employment, creating demand complementarities for the microenterprises sector that spur the MFIs intensive growth, but at the same time potentially limiting the MFIs extensive growth.

\section{Conclusions}

In this paper the author has looked at whether the activity of microfinance institutions is linked with a domestic economy or not. Following research from all over the world, this research was conducted in the microfinance sector in Vietnam.

The paper has shown that in general, the scale of microfinance activities in Vietnam has increasingly expanded since 2005. Moreover, using five years (2010-2015) of data from the microfinance market in Vietnam, the author looked at the relations between two macro indicators (GDP growth and FDI inflow growth) and three indicators measuring the growth of the microfinance sector (growth of asset, growth of the gross loan portfolio and growth of deposit) by using descriptive statistics. It has been found that the growth of GDP and gross loans portfolio more or less have a relation over 5 years. Likewise, FDI inflow growth seems to have a link with asset development.

This result also opens up several avenues for future research. Further studies could be performed by examining a quantitative method which could be used to test the results.

\section{References}

ADB (2014). Sector Assessment: Microfinance. Documents prepared for the loan small program (SP2) - Development microfinance sector Programme in Vietnam. 
Ahlin, C., Lin, J., Maio, M. (2011). Where does microfinance flourish? Microfinance institution performance in macroeconomic context. Journal of development economics, 95 (2), 105-120.

Ahlin, C., Lin, J. (2006). Luck or skill? MFI performance in macroeconomic context. BREAD Working paper No. 132, October.

Goenka, A., Henley, D. (2010). Southeast Asia's credit revolution: From moneylenders to Microfinance. United Kingdom: Milton Park.

Gonzalez, A. (2007). Resilience of microfinance institutions to national macroeconomic events: An economic analysis of MFI asset quality. Microfinance Information Exchange, Inc.

Hermanto, B., Astuti, D.R. (2013). The impact of macroeconomic on the financial performance of the microfinance institutions in Java Island, Indonesia. Universitas Indonesia, Graduate School of Management Research Paper, $13-08$.

Imai, K.S., Gaiha, R., Thapa, G., Annim, S.K., Gupta, A. (2011). Performance of microfinance institutions - a macroeconomics and institutional perspective. Discussion paper series Kobe University, 22.

Loncar, D., Novak, C., Cicmil, S. (2009). Global Recession and Sustainable Development: The Case of Microfinance Industry in Eastern Europe. Microfinance gateway.

Marconi, R., Mosley, P. (2005). Bolivia during the global crisis 1998-2004: towards a macroeconomics of microfinance. Sheffield economic research paper series, June.

McGuire, P.B., Conroy, J.D. (1998). Effects on microfinance of 1997-1998 Asian financial crisis. The foundation for development cooperation, November.

Muriu, P.W. (2011). Microfinance profitability. United Kingdom: Birmingham Business School.

Patten, R.H., Rosengard, J.K., Johnston, D.E. (2001). Microfinance success amidst macroeconomic failure: The experience of bank Rakyat Indonesia during the East Asian crisis. World Development, 29 (6), 1057-1069.

The Microfinance Information Exchange: https://www.themix.org/mixmarket.

United Nation (2015). Inclusive finance in the Asia-Pacific region: trend and approaches. International conference on financing and development. Ethiopia.

Vanroose, A. (2008). What macro factors make microfinance institutions reach out? CEB working paper, 8 (036).

Wooley, J. (2008). Microfinance performance and domestic GDP growth: Testing the resiliency of microfinance institutions to economic change. Stanford Journal of Microfinance, 1.

World Bank database: http://data.worldbank.org.

World Bank (2012). Well begun, not yet done: Vietnam remarkable progress on poverty reduction and the emerging challenges. Vietnam: World Bank working paper.

\section{SPLOT WYDARZEŃ MIĘDZY WZROSTEM INSTYTUCJI MIKROFINANSOWANIA I KONTEKSTU MAKROEKONOMICZNEGO W WIETNAMIE}

Streszczenie: Celem opracowania jest przedstawienie przeglądu rozwoju sektora mikrofinansowania w Wietnamie i zbadanie związku między rozwojem mikrofinansów instytucji i krajowych czynników ekonomicznych. W szczególności po zapoznaniu z poprzednimi artykułami prowadzonymi na całym świecie, w tym artykule analizuję na rynku wietnamskim relację w ciągu pięciu lat (2010-2015) danych z wietnamskich instytucji mikrofinansowania pod opisową metodą statystyczną. Stwierdzono, że wzrost produktu krajowego brutto (PKB) i portfela kredytowego brutto w mniejszym lub większym stopniu mają związek. Podobnie, bezpośrednie inwestycje zagraniczne (BIZ), oraz wzrost napływu wydaje się mieć związek z rozwojem zasobów. Wynik ten otwiera również kilka możliwości dla przyszłych badań. Dalsze badania można przeprowadzić analizując w sposób ilościowego badania wyników.

Słowa kluczowe: mikrofinanse, makroekonomia, wzrost

\section{Citation}

Tran H.T. (2017). The nexus Between the Growth of Microfinance Institutions and the Macroeconomic Context in Vietnam. Finanse, Rynki Finansowe, Ubezpieczenia, 1 (85), 721-730. DOI: 10.18276/frfu.2017.1.85-57. 